\title{
A EFETIVIDADE DO PRINCÍPIO DA MANUTENÇÃO DO VALOR REAL DOS BENEFÍCIOS PREVIDENCIÁRIOS*
}

\author{
Maria amélia Almeida Jenos de Carvalho
}

I - A evolução histórica da questão dos reajustamentos previdenciários - da unificação do tratamento legislativo (edição da Lei Orgânica da Previdência Social - L.3.807/60) até a CF de 1988; II - O princípio da manutenção do valor real dos benefícios previdenciários; - III - Efetividade das normas jurídicas; $I V-O$ controle de constitucionalidade no Brasil; A - Supremacia da Constituição; B-Modalidades de controle de constitucionalidade; $V-O$ poder-dever dos Juizes ao julgar: limites; VI-Uma proposta

I - A evolução histórica da questão dos reajustamentos previdenciários - da unificaçāo do tratamento legislativo (edição da Lei Orgânica da Previdência Social - L.3.807/60) até a CF de 1988

Para melhor compreensão da questão dos reajustamentos previdenciários, é de bom alvitre analisar o tratamento histórico dado à matéria.

Ana Maria Wickert Theisen', Juíza Federal do TRF da $4^{\text {a }}$ Região, traça minucioso estudo da evolução dos critérios de reajustamento dos benefícios previdenciários e das principais polêmicas suscitadas a respeito e que podemos resumir na seguinte ordem cronológica como preliminar da proposta que queremos formular:

1 In “Direito Previdenciário - Aspectos materiais, processuais e penais". 2a edição, Ed. Livraria do Advogado.

* Trabalho apresentado no IV Encontro de Magistrados Federais do TRF da $2^{\mathrm{a}}$ Região, de 18 a 21 de novembro de 1999, Club Mediterranée de Rio das Pedras - RJ 
- L.3.807 de 26/08/60 (Lei Orgânica da Previdência Social) - em seu artigo 67 determinou que o reajustamento dos benefícios se desse sempre que os índices dos salários de contribuição dos segurados ativos ultrapassasse em mais de $15 \%$ os do ano do último reajuste.

- Decreto-lei 66 de 21/11/66 - alterou o artigo 67 supra vinculando os reajustes dos benefícios previdenciários à variação da Política Salarial, computando o percentual aplicado ao salário mínimo apenas 60 adias após sua alteração;

- Lei 5.890 de 1973 - altera de novo o artigo para determinar a imediata aplicação da variação da Política Salarial, de forma imediata e não mais diferindo seus efeitos;

O Decreto 77.077 de janeiro de 1976 (Consolidação das Leis da Previdência Social) - em seu artigo 30 mantém o critério anterior mesmo após a edição da Lei 6.205 de 29/04/75 que descaracterizou o salário mínimo como fator de correção monetária;

- Lei 6.708 de 30/10/79 - estabelece a correção automática dos salários cujo valor passou a ser corrigido semestralmente pela variação do INPC e dividiu os assalariados em faixas salariais. Por extensão, tal critério aplicava-se também aos benefícios previdenciários.

Entretanto, o enquadramento e o reajuste eram feitos de forma errônea pelo INPS gerando prejuízo aos beneficiários. Em primeiro lugar, a autarquia passou a aplicar o critério da proporcionalidade, ou seja, o índice de variação da política salarial era repassado proporcionalmente ao mês da concessão, no que diz respeito ao primeiro reajuste dos benefício, sem que a lei assim o determinasse. Assim, desde a vinculação dos benefícios à Política Salarial (1966), a autarquia efetuava erroneamente o reajuste proporcional.

Em segundo lugar, ainda quanto ao enquadramento deve-se explicar que os salários eram divididos em faixas salariais às quais eram atribuídos índice de reajuste inversamente proporcionais (quanto mais elevado o nível da faixa, menor o reajuste atribuído). Com isso, uma vez editada a alteração da Política Salarial com a divulgação do novo valor do salário mínimo, a autarquia classificava ou enquadrava os benefícios por faixas de acordo com o valor revogado, fazendo com que muitas vezes os beneficiários mudassem de faixa, percebendo índice menor. Este equívoco veio a ser corrigido com a edição do Decreto-lei 2.171/84 que esclareceu que o enquadramento deveria ser feito pelo novo valor do salário mínimo . Em 26/05/87, a L.7.604, reconhecendo o equívoco praticado no passado, determinou a retificação da atualização no período de nov/79 a mai/84, sem efeitos financeiros pretéritos.

Os dois equívocos acima mencionados, ensejaram a edição da Súmula 260 do extinto TFR, cuja aplicação, nos dois aspectos, encontra-se de há muito superada. 
- Decretos-lei 2.284 de 10/03/86 (Plano Cruzado) e 2.302 de 21/11/86 - instituíram a escala móvel de salários e o reajuste automático de salários quando a variação acumulada do IPC no ano atingisse $20 \%$ a contar da última data-base. Todo mês era verificada a variação do IPC de forma a constatar ou não o atingimento do patamar referido e o repasse aos benefícios do resíduo nos reajustes seguintes.

- Lei 7.604 de 26/05/87 - determinou o reajuste do benefícios de acordo com a Política Salarial e conforme as disponibilidades financeiras do Sistema Nacional de Previdência Social.

Em 12/06/87 é editado o Decreto-lei 2.335 que extinguiu o gatilho automático pela variação do IPC e instituiu a URP. Entretanto, foi assegurado aos beneficiários o repasse de $20 \%$ da variação do IPC acumulado no mês anterior, isto é, maio de 1987.

O Decreto-lei 2.351 de $07 / 08 / 87$ criou um dúplice regime salarial instituindo:

a) Salário mínimo de referência que correspondia ao antigo salário mínimo e ao qual ficavam vinculados os salários e os benefícios previdenciários, utilizado também na aplicação de índice de atualização monetária;

b) Piso Nacional de Salários - que correspondia à contraprestação mínima devida e paga diretamente pelos empregadores aos trabalhadores, com valor mais elevado que a espécie anterior.

Este sistema dúplice perdurou até a edição da L.7.789 de 03/07/89. Neste período, por expressa determinação legal, no que pertine a reajustamento de benefícios ou cálculo de correção monetária de liquidação, o certo é utilizar-se o salário mínimo de referência.

- Constituição Federal de 1988 - criou o salário mínimo nacionalmente unificado (conceito em que apenas o salário mínimo de referência se enquadrava); vedou vinculação ao salário mínimo para qualquer fim; instituiu no ato das disposições transitórias o critério provisório de reajustamento dos benefícios previdenciários então em manutenção pela equivalência inicial em número de salários mínimos e criou o princípio da manutenção do valor real dos benefícios, que passamos a estudar.

II - O princípio da manutenção do valor real dos benefícios previdenciários

A Constituição Federal de 1988 foi a primeira a tratar sistematicamente da seguridade social conferindo-lhe um capítulo próprio no Título VIII da Ordem Social.

Neste capítulo encontramos os artigos 194 e 201 que com a redação dada pela Emenda Constitucional $n^{\circ}$ 20/98 dispõem: 
Art. 194 - A seguridade social compreende um conjunto integrado de ações de iniciativa dos Poderes Públicos e da sociedade. destinadas a assegurar os direitos relativos à saúde, à previdência e à assistência social.

Parágrafo único - Compete ao Poder Público, nos termos da lei, organizar a seguridade social, com base nos seguintes objetivos:

IV - irredutibilidade do valor dos benefícios;

Art. 201 - A previdência social será organizada sob a forma de regime geral, de caráter contributivo e de filiação obrigatória, observados critérios que preservem o equilíbrio financeiro e atuarial, e atenderá, nos termos da lei, a: ... $\S 4^{\circ}-$ É assegurado o reajustamento dos benefícios para preservar-lhes, em caráter permanente, o valor real, conforme critérios definidos em lei. ...

Note-se que os dois princípios supra referidos (o da irredutibilidade de benefícios e o da manutenção do valor real) já encontravam amparo na Constituição desde sua promulgação, respectivamente no inc.V do art. 194 e no $\$ 2$ do art. 201, não tendo sofrido alterações com a Reforma Previdenciária.

Regulamentando o Capítulo da Seguridade Social, foram editados os Planos de Custeio e o de Benefícios do Regime Comum Previdenciário, respectivamente Leis $\mathrm{n}^{\circ} 8.212$ e 8.213 de julho de 1991 que, por sua vez, foram regulamentadas em dezembro do mesmo ano com a edição dos decretos pertinentes.

A Lei 8.212/91 dispunha:

Art. $6^{\circ}$ - Fica instituído o Conselho Nacional de Seguridade Social. órgão superior de deliberação colegiada, com a participação da União, dos Estados, do Distrito Federal. dos Municípios e de representantes da sociedade civil. ...

Art. $7^{\circ}-$ Compete ao Conselho Nacional da Seguridade Social:

VI - estudar, debater e aprovar proposta de recomposição periódica dos valores dos benefícios e dos salários-de-contribuição. a fim de garantir de forma permanente a preservação de seus valores reais; ;...

Note-se que este dispositivo encontra-se revogado já que o Conselho Nacional de Seguridade Social foi extinto conforme alterações introduzidas pela Medida Provisória $n^{\circ} 1.911$ de dezembro de 1998 na L. 9.649 de 27/05/98 que dispõe sobre a organização da Presidência da República e dos Ministérios, sem que suas atribuições tenham sido transferidas a qualquer outro órgão da estrutura do Ministério da Previdência e da Assistência Social.

O direito subjetivo ao reajustamento do benefício para preservação de seu valor real assegurado na Constituição vem igualmente insculpido na L. 8.213/91, em seu art. 41 , inc.I.

Vemos, assim, que o constituinte conferiu aos benefícios previdenciários garantias maiores e até então inéditas; ao lado da irredutibilidade de seu valor nominal 
(garantia igualmente conferida aos salários no art. $7^{\circ}$, inc. VI), tornou obrigatório o reajustamento periódico do benefício sempre que constatada perda de seu valor real.

A referida norma é dotada de alto nível de abstração e desde a promulgação da Carta tornou-se um desafio imposto aos aplicadores do Direito a tarefa de definir o que fosse "valor real".

Sem maiores delongas que demandariam uma pesquisa multidisciplinar, envolvendo conceitos até mesmo de Economia, vamos direto ao que hoje parece ser consenso doutrinário endossado pelo Eg. STF. Conforme decisões reiteradas dos Tribunais Superiores, entende-se que o conceito de valor real do benefício previdenciário é indissociável do conceito de valor aquisitivo e, consequientemente, indissociável da idéia de preservação do benefício dos efeitos da inflação.

Desta forma, o $\S 4$ do art. 201 contém norma programática que impõe ao legislador ordinário a tarefa de estabelecer o reajustamento do benefício toda vez que houver perda do valor aquisitivo inicial ou seja, do valor aquisitivo da renda mensal inicial, perda essa que ocorre através do fenômeno inflacionário.

Ao julgar o Mandado de Segurança $n^{\circ}$ 1.233-DF impetrado para assegurar o reajuste dos benefícios previdenciários em $147,06 \%$ (mesmo índice aplicado para reajuste dos salários-de-contribuição em setembro de 1991) o Eg. STJ, através do voto do Min. Garcia Vieira, ressaltou dois aspectos de suma importância decorrentes dos princípios constitucionais da manutenção do valor real e da garantia da fonte de custeio: em primeiro lugar lembrou que o salário-de-contribuição deveria ser reajustado na mesma época e com os mesmos índices de reajustamento dos benefícios de prestação continuada, conforme dispunha o parágrafo único do art. $20 \mathrm{da} \mathrm{L}$. $8.212 / 91$, hoje substituído pelo art. $29, \S 1$. Assim, se um é reajustado, o outro fator também o será.

O segundo aspecto merece ser transcrito face à clareza que trouxe à discussão acerca do princípio da manutenção do valor real:

"O legislador constitucional assegurou, em suas disposições permanentes a irredutibilidade do valor dos benefícios (art. 194, IV) e seu reajustamento para “... preservar-lhes, em caráter permanente, o valor real, conforme critérios definidos em lei”.

Ora, é evidente que o legislador ordinário não poderia desconhecer e desrespeitar estes dois mandamentos, o da irredutibilidade e preservação do valor real dos benefícios. Os seus aumentos não poderiam ser inferiores aos índices da inflação. Mesmo após a implantação definitiva dos planos, os benefícios e as contribuições devem ser reajustados, na mesma época e com os mesmos índices, nunca inferiores aos da inflação, para ser respeitada a irredutibilidade e preservar o valor real dos benefícios e garantir a fonte de custeio."

No mesmo sentido é a posição do Eg. STF:

“... . Com o preceito* objetivou-se cobrir o espaço de tempo até a vigência de nova legislação previdenciária a ser editada em harmonia com os princípios insculpidos no artigo 201 do corpo permanente da Constituição. Ora, constata-se 
que o $\S 2^{\circ}$ do mencionado artigo é categórico ao assegurar o reajustamento dos benefícios para preservar-lhes, em caráter permanente, o valor real, remetendo à lei, enquanto o $\S 3^{\circ}$ dispõe sobre a atualização dos salários de contribuição computados no cálculo do benefício.

Evidentemente, a manutenção do poder aquisitivo dos benefícios previdenciários, fez-se, em primeiro lugar e relativamente ao período que antecede a data da aquisição do direito, de acordo com a atualização dos salários de contribuição e, em segundo lugar, relativamente ao tempo posterior, considerada a inflaçāo, havendo, portanto, data-base própria. ...

* o preceito aqui referido é o art. 58 do ADCT

\section{(AI 188298-1, Min Marco Aurélio, in DJ I de 07/04/97, pg. 11.009)}

Compete, assim, ao Congresso Nacional dispor sobre o regime de reajustamento dos benefícios, fixando datas, periodicidade e índices. Está, porém, como Poder Constituído, sujeito aos limites constitucionais, dentre os quais situa-se o dever a ele imposto de assegurar aos titulares de benefícios previdenciários a preservação destes últimos contra os efeitos malignos da inflação a qual acarreta perda de valor aquisitivo da moeda.

Indo mais além, ainda ANA MARIA WICKERT THEISEN entende que todo reajustamento deverá necessariamente estar amparado em um índice oficial de correção monetária, sob pena de estar sendo fraudada a garantia constitucional:

"Ora, se o Texto Maior fala em critérios, o que a lei infraconstitucional deve fazer, no desiderato de regulamentar o dispositivo, é indicar um índice oficial, baseado em indexadores oficiais (os quais obedecem a uma mecânica de cálculo previamente estabelecida, de molde a refletir a variação inflacionária). Não há autorização para que o le gislador, livremente, escolha um percentual qualquer, sem lastro no fenômeno inflacionário, de cujos efeitos, aliás, os reajustes procuram precaver os benefícios, assegurando seu poder liberatório." ${ }^{2}$

Desta forma, podemos concluir que ao legislador é dado escolher qualquer índice inflacionário oficial, mesmo o que houver apresentado menor variação no período de apuração Entretanto, uma vez verificada a perda do poder de compra do benefício em manutenção em relação ao seu valor inicial (RMI) e em cotejo com todos índices inflacionários oficiais, o beneficiário passa a ter direito subjetivo à reposição da perda, cabendo ao legislador eleger um índice dentre a gama de índices oficiais existentes. Deve ainda dispor sobre a forma como se dará o reajustamento no que pertine a data e periodicidade. Não cabe ao segurado pretender o índice que mais lhe convenha já que a Constituição outorgou ao Congresso Nacional a tarefa de

2 op. cit. pg. 194. 
dispor sobre o regime de reajustamento. Entretanto, o poder atribuído ao Poder Legislativo encontra limite no princípio estudado.

Como então agir quando no exercício da competência que lhe é atribuída o Legislador infringe o dispositivo constitucional ou ao contrário, se se omite de exercê-la? Tratando-se de norma programática, isto significa que a mesma deve restar indefesa? A questão merece uma digressão.

\section{III - Efetividade das normas jurídicas}

É preciso lembrarmos que existência, validade e eficácia dos atos jurídicos são atributos não se confundem.

$\mathrm{O}$ ato jurídico se diz existente quando presentes seus elementos constitutivos previstos na lei. Uma vez existente, ele será válido se os elementos constitutivos estiverem de acordo com o estabelecido na norma no que pertine, por exemplo, competência para sua edição, observância do processo de criação etc... Assim, por exemplo, uma lei declarada inconstitucional é existente porém inválida.

O ato válido, por sua vez, será eficaz se idôneo a produzir os efeitos nela previstos. No período de vaccatio legis, por exemplo, uma lei é ineficaz. Especificamente no tocante à classificação das normas constitucionais tradicional estabelecida por José Afonso da Silva, assegura-se às normas programáticas uma "eficácia mínima" ou seja, ela produz efeitos independentemente de sua regulamentação no mínimo para revogar a lei que lhe seja contrária e eivar de inconstitucionalidade a norma posterior que seja editada contrariamente a seu sentido.

Luis Roberto Barroso analisa ainda um quarto atributo dos atos jurídicos e em especial das normas jurídicas: a efetividade. Efetividade equivaleria em suas palavras à eficácia social ou reconhecimento pela sociedade da existência da norma, operando-a no mundo dos fatos:

"A efetividade significa, portanto, a realização do Direito, o desempenho concreto de sua função social. Ela representa a materialização, no mundo dos fatos, dos preceitos legais e simboliza a aproximação, tão íntima quanto possível entre o dever-ser normativo e o ser da realidade social." ${ }^{3}$

Podemos dizer assim que, se a efetividade da norma depende de sua aplicação real, pode e deve o Poder Judiciário garantir este atributo. Podemos ainda dizer que a norma constitucional que abriga o princípio da manutenção do valor real do benefício só será efetiva se forem editadas leis que realmente mantenham o poder de compra original do benefício, considerando a Economia inflacionária em que ainda hoje vivemos. Como garantir, então, a efetividade?

3 in "O Direito Constitucional e a efetividade de suas normas - limites e possibilidades da Constituição Brasileira”, 1990, pg. 77, Ed. Renovar. 


\section{A - Supremacia da Constituição}

A Constituição tem histórica e esssencialmente a função de limitar os Poderes Constituídos ao lado da função de organizar e instituir o próprio Estado.

As edições das primeiras Cartas Constitucionais receberam o nome de Movimento Constitucionalista e foram a fonte e base do chamado Estado de Direito contendo o elenco mínimo de direitos e garantias individuais. A evolução histórica e as novas demandas sociais levaram igualmente à evolução do conceito de Constituição e de sua finalidade. Entramos então no chamado Estado Social, em que os documentos básicos passaram a assegurar não apenas direitos dos indivíduos face ao Estado mas também enquanto trabalhador.

Temos assim que a Constituição dá origem ao próprio Estado e que os Poderes que o constituem são Poderes Derivados e, portanto, limitados pela própria Lei Fundamental. É dela que se originam todas as demais normas que nela encontram seu fundamento de validade. Daí comumente falar-se em supremacia da Constituição significando a submissão dos Poderes de Estado e dos atos por ele praticados aos princípios constitucionais.

Conseqüentemente, toda norma editada em desacordo com a Constituição, seja quanto ao processo de sua criação seja quanto a seu conteúdo, padece de vício de inconstitucionalidade sendo nula ou inexistente. no dizer de parte da doutrina (ex: Francisco Campos).

Também a inércia de qualquer dos Poderes do Estado pode ser eivada de inconstitucionalidade sempre que deixar de editar ato de sua competência exigido pela Constituição e necessário para eficácia plena do dispositivo.

Do exposto surgiu a necessidade de se instituir mecanismos de fiscalização da adequação da conduta dos Poderes Constituídos à Lei Fundamental, o que se deu através do controle de constitucionalidade.

\section{B - Modalidades de controle de constitucionalidade}

Uma norma pode ser inconstitucional por diversos aspectos, gerando pluralidade de modalidades de controle.

Há inconstitucionalidade formal ou material segundo o vício esteja relacionado ao processo de formação da norma ou a seu conteúdo. Por outro lado a inconstitucionalidade pode dar-se por ação ou por omissão. ou seja, o vício tanto pode surgir da edição de lei ou ato normativo em afronta ao dispositivo constitucional quanto da inércia do Poder Público competente em editar a lei ou ato normativo necessário para a eficácia plena e aplicabilidade da norma; neste caso é pressuposto desta espécie de controle a inexistência da norma ou a existência de norma que disponha de forma insuficiente sobre a matéria ${ }^{4}$.

4 in Clèmerson Merlin Clève, "A fiscalização abstrata de constitucionalidade no Direito Brasileiro", Ed. RT, 1995, pg.42. 
O ordenamento jurídico brasileiro admite, por outro lado, dois sistemas de controle de constitucionalidade: o controle pela via principal (ação direta de inconstitucionalidade que pode assumir a forma interventiva) ou pela via de exceção.

A ação direta de inconstitucionalidade de lei ou ato normativo federal ou estadual é prevista no art. 102, inc. I, alínea "a" da Constituição: a competência para julgá-la é do Eg. STF, órgão máximo de guarda e interpretação da lei fundamental, e a legitimidade para propô-la é conferida um elenco fechado de pessoas e órgãos contido no art. 103. Embora haja alguma divergência doutrinária ${ }^{5}$, a maioria entende que a ação é de cunho declaratório da nulidade da lei ou ato normativo, produzindo efeitos retroativos (extunc), e erga omnes. No caso de vir a ser declarada a inconstitucionalidade por omissão, ao eg. STF compete apenas dar ciência de sua decisão ao poder infrator a fim de que adote as providências necessárias as quais, no caso de órgão administrativo, deverão ser tomadas em 30 dias.

Considerando ainda a hipótese de omissão normativa, a Constituição prevê também dois outros instrumentos de fiscalização: o mandado de injunção e a iniciativa legislativa popular. O Mandado de Injunção vem previsto no art. 5, inc. LXXI da Constituição e a iniciativa popular no art. 61, § 2, regulamentado pela L. 9.709/98.

O Mandado de Injunção pressupõe uma lacuna legislativa ou ausência de norma e que esta ausência inviabilize o exercício de direito subjetivo constitucionalmente previsto, no que diverge da ação direta de inconstitucionalidade já que esta objetiva o resguardo da Constituição e não de um direito individual específico ${ }^{6}$. O remédio constitucional, ao contrário da ação direta, não se limita a declarar a mora do legislador. Embora de conteúdo esvaziado pelo Eg. STF que o equiparou em efeitos à ação declaratória de inconstitucionalidade, parece-nos claro que, conforme a lição do Mestre Hely Lopes Meirelles ${ }^{7}$, o remédio constitucional somente seria eficaz se ao órgão julgador fosse possibilitado integrar a norma no caso concreto, preenchendo a lacuna de acordo com os princípios gerais de direito, a analogia, costumes e sobretudo a eqüidade.

Copiando o sistema de controle americano, admitimos ainda o sistema de controle difuso ou incidental pelo qual a qualquer órgão judiciário é dado declarar incidenter tantum a inconstitucionalidade de lei ou ato normativo como questão prejudicial da análise do mérito da ação. A declaração de inconstitucionalidade não integra o dispositivo da sentença e não transita em julgado, operando efeitos apenas entre as partes do processo. Esgotadas as vias recursais ordinárias, a questão pode vir a ser submetida ao Eg. STF através de recurso extraordinário. Neste caso, entendendo a Corte Máxima pela existência de vício, deverá dar ciência desta decisão definitiva ao Senado Federal que, por sua vez, pode suspender a execução de lei julgada inconstitucional, situação em que a decisão passará a ter efeitos erga omnes e retroativos.

5 Francisco Campos entende que a norma declarada inconstitucional é inexistente e não nula.

6 V. Clèmerson Clève, op. cit. pg.230.

7 in "Mandado de Segurança. Ação Popular. Ação civil pública. Mandado de Injunção e habeas data ". $13^{\mathrm{a}}$ ed., pg. 135, Ed. RT. 
No controle incidental o órgão julgador subtrai o caso concreto da órbita de eficácia da norma impugnada como se ela não existisse, nas palavras de Lucio Bittencourt.

Voltando à análise dos reajustamentos previdenciários, vemos que desde a edição da Constituição dita Cidadã, inúmeras foram as leis e medidas provisórias editadas para discipliná-los e inúmeras as ações impugnando os critérios adotados alegando-se, em de forma geral a infringência do princípio constitucional da manutenção do valor real do benefício. Em $90 \%$ das ações propostas o pedido ou é mal formulado revelando completo desconhecimento por parte dos patronos acerca do direito previdenciário ou pretendem que seja fixado como critério permanente de reajuste a vinculação à equivalência em número de salários mínimos o que, além de vedado na parte permanente da Constituição não é garantia de efetividade do princípio constitucional. Resta questionar: como proceder ao controle de constitucionalidade das normas que versam sobre reajuste previdenciário de forma a preservar o princípio da divisão de poderes?

\section{$\mathrm{V}-O$ poder-dever dos Juízes ao julgar: limites}

O exercício da função jurisdicional é regido por alguns princípios basilares que assumem especial relevo quando o juiz se defronta com lacunas legislativas ou com hipóteses em que, dado o vício de inconstitucionalidade da norma (e consequiente nulidade da norma) a mesma torna-se inaplicável ao caso concreto.

Em primeiro lugar cumpre citar o principio da indeclinabilidade da jurisdição insculpido no art. 126 da lei processual segundo a qual ao juiz não é dado eximir-se de sentenciar ou de decidir alegando lacuna ou obscuridade da lei, caso em que poderá socorrer-se das normas legais e na ausência destas, da analogia, dos costumes e dos princípios gerais do direito, cabendo ainda o uso da equiidade nos casos expressamente permitidos por lei. Nas palavras de José Roberto dos Santos Bedaque, Juiz do Tribunal de Alçada do Estado de São Paulo,: "a Jurisdição é a atividade estatal destinada a garantir a eficácia prática do ordenamento jurídico" ${ }^{8}$. Onde se lê eficácia prática, entenda-se efetividade

Preciosas, nesse sentido, as lições de dois autores franceses, um senador e uma professora de direito, Hubert Haenel e Marie-Anne Frison-Roche autores do livro "Le juge et le politique" ( editora Presses Universitaires de France, 1998) em que fazem uma análise do papel do juiz na sociedade moderna e as expectativas da sociedade, em especial a francesa, quanto à sua atuação. Fugindo do positivismo puro que impera e buscando soluções para que a Justiça cumpra seu papel — que é o de fazer Justiça mais do que simplesmente aplicar a lei - trazem eles conclusões que podemos resumir nos seguintes tópicos: 
- o juiz deve zelar para que o direito e o justo coincidam;

- o direito não é um fim em si mesmo mas um instrumento na busca da Justiça;

- atualmente, mais que o legislador, é o juiz quem encarna o espírito de justiça;

- a submissão do juiz às leis não pode implicar inferioridade em relação ao legislador notadamente porque este deveria exercer seu poder para realizar a Justiça;

- quando o direito positivo excede os limites do Justo, a regra segundo a qual o juiz dever tornar a lei efetiva torna-se ilegítima.

É verdade que o juiz não se confunde com o legislador; ambos são agentes políticos cujos atos editados no exercício de suas funções típicas são manifestações de vontade do próprio Estado. Mas, se por um lado o Legislativo edita normas gerais e abstratas, a sentença representa a norma concreta aplicável ao caso submetido ao crivo do Poder Judiciário no exercício irrecusável de sua função quando deve zelar pela preservação da Lei Maior:

"Cercado de respeito e autoridade, o Juiz tem liberdade de pronunciar o Direito segundo as circunstâncias do caso. Nessa tarefa, seu papel é sem dúvida criador. Não chega ao extremo de proferir sentenças contra legem ....Mas há princípios legais que autorizam o emprego dos métodos mais nobres e inteligentes de hermenêutica - o teleológico e o sistemático - , de modo a afastar o literal, para o apelo à eqüidade e à Justiça em concreto. Invoca-se, então, a regra basilar do art. 5 da Lei de Introdução ao Código Civil: "Na aplicação da lei, o Juiz atenderá aos fins sociais a que ela se dirige e às exigências do bem comum".

Desta forma não se pode negar a relativa função criadora de Direito de que se reveste a atividade jurisdicional.

Diz Athos Gusmão Carneiro' ${ }^{10}$.

"Em duas hipóteses, todavia, a Constituição Federal atribui ao Poder Judiciário, mais especificamente ao STF e aos Tribunais de Justiça, o exercício, embora sob vestes jurisdicionais, de uma atividade legislativa, porque não vinculada à aplicação do direito a um caso concreto.

Referimo-nos, em primeiro lugar, à ação direta de inconstitucionalidade. ... Em segundo lugar, a Emenda Constitucional $n^{\circ} 3$ de 17/03/93, criou a ação declaratória de constitucionalidade de lei ou ato normativo federal, para cujo ajuizamento são legitimados os Presidente da República, as Mesas do Senado e da Câmara dos Deputados e o Procurador-Geral da República (art. 103, § 4) e de competência do STF."

9 in "O Judiciário e a Constituição", artigo do professor Galeno de Lacerda ("O juiz e a Justiça no Brasil"), 1994, pg.129, Ed. Saraiva.

10 in "Jurisdição e Competência", 7" edição, Ed. Saraiva, pgs. 16/17. 
Ousando ampliar o pensamento do Mestre, entendemos que a atividade criadora ou legislativa do Judiciário é exercida também no controle de constitucionalidade incidental ou pela via de exceção já que também neste caso, uma vez concluindo o Juízo pela existência do vício, a norma inquinada será declarada inconstitucional e nula, retirando-se o caso concreto da órbita de sua eficácia devendo ser aplicada outra norma ou princípio de forma a fim de garantir-se ao litigante o exercício do direito subjetivo que o ordenamento constitucional lhe confere.

Vemo-nos então diante das seguintes premissas extraídas de nosso ordenamento jurídico:

- a Constituição é a lei fundamental que origina o Estado e que constitui o fundamento de validade de todas as demais normas à qual se submetem os Poderes Constituídos no exercício de suas atribuições;

- toda norma constitucional é dotada de eficácia mínima que é a de impedir a edição de lei ou ato normativo que a afronte e que, nesse sentido, será inconstitucional e portanto nulo;

- como forma de assegurar o respeito à Constituição e seus princípios instituiu-se o controle de constitucionalidade;

- o controle de constitucionalidade é exercido por qualquer órgão jurisdicional pela via da exceção, caso em que os efeitos de sua decisão serão restritos às partes do processo e ao caso concreto que lhe é submetido;

- a afronta aos dispositivos constitucionais tanto pode se dar sob a forma comissiva (edição de norma viciada tanto em seu aspecto formal quanto material) ou omissiva (quando o Poder competente deixa de editar a lei ou ato normativo necessários para a plena eficácia da norma constitucional);

- a Constituição confere ao beneficiário do Regime Comum Previdenciário o direito subjetivo a reajustamento que assegure o valor real inicial de seu benefício, o que, segundo os Tribunais Superiores, significa manutenção do poder aquisitivo inicial, resguardando o valor da RMI especificamente dos efeitos da inflação;

- a Jurisdição é garantia da efetividade das normas e do exercício dos direitos subjetivos;

- ao Juiz não é dado escusar-se de decidir, devendo julgar nos limites da lide que lhe é exposta ainda que se defronte com lei ou ato normativo nulo e se veja obrigado a utilizar-se dos princípios gerais de direito, da analogia e dos costumes para decidir a questão subtraída da órbita de eficácia da norma viciada.

Consideradas as premissas supra referidas como conciliá-las no momento de analisar e julgar as causas trazidas à Justiça Federal que versem sobre reajustamento de benefícios previdenciários postulando a reposição de perdas ocorridas pelo descumprimento do princípio constitucional da manutenção do poder real?

\section{VI - Uma proposta}

Em primeiro lugar cumpre verificar no caso concreto se houve lesão ao princípio constitucional da manutenção do valor real. 
Neste caso - e mais especificamente considerando que os benefícios aos quais se aplica o princípio retro são obrigações de trato sucessivo cujo regime de reajustamento pode ser alterado pelo legislador, sendo incabível pretender a submissão a um regime imutável - a primeira obrigação do beneficiário e providência necessária a ser tomada ao redigir a inicial é, não só trazer a prova da titularidade do benefício com a juntada do documento pertinente, como também identificar o período de reajuste que considera equivocado ou o indice cuja aplicação considera errônea por parte do Legislador. Isto não impede que o autor da ação simplesmente demonstre a perda do poder aquisitivo ao longo do tempo desde a concessão sem identificar de pronto o índice impugnado e a lei que o instituiu mas a inicial deverá ser apta a permitir ao Juiz (que conhece do Direito) identificar a(s) norma(s) impugnada(s) possibilitando a análise de sua constitucionalidade. Entretanto neste último caso, a perda do poder aquisitivo deverá ser verificada entre cada novo reajustamento, pois cada novo regime instituído com base em uma nova lei deverá ter sua constitucionalidade analisada de per si, cotejando-se esse novo diploma com a Carga Magna. Explico-me.

É claro que uma lei que estabeleça um reajustamento inferior à inflação apurada dentro da periodicidade do regime, além de inconstitucional provoca perdas cujos reflexos vão se verificar nos reajustes seguintes. Entretanto, nem por isso uma lei futura que estabeleça um novo regime e índice de reajustamento baseado na variação inflacionária poderá ser impugnada de inconstitucional pelo só fato da existência daqueles reflexos. $O$ juiz tem sua atuação limitada. por isso exige a lei adjetiva que a inicial contenha pedido certo e causa de pedir determinada. É também a única forma pela qual a parte pode obter algum sucesso em sua demanda.

Assim, a juntada dos comprovantes de recebimento do benefício é indispensável para a verificação de perdas e, conseqüentemente, da procedência do pedido. Não é necessária desde logo a indicação de um percentual determinado de perdas nem mesmo a indicação de um índice previamente escolhido pelo autor para reger o reajustamento de seu benefício. Ao contrário, se não existe direito subjetivo a determinado índice inflacionário, mas sim e apenas à manutenção do poder aquisitivo, a escolha de um medidor específico pelo autor (como por exemplo, o índice de maior apuração no período) pode acarretar a improcedência do pedido já que o Juiz deve julgar nos limites da lide e não pode desconsiderar a faculdade de o legislador optar pelo índice que considerar melhor para o reajustamento no novo regime.

Uma vez proposta corretamente a ação, e considerado o teor do princípio constitucional em cotejo, temos que, face à natureza da causa, a realização de perícia contábil é indispensável e pode ser determinada pelo Juízo independentemente do pedido da parte" não apenas com base no princípio do livre convencimento e da

11 " Poderá ainda determinar a audiência de ofício de qualquer das partes ou de testemunhas referidas, ou a realização de perícias ou de inspeções. embora não requeridas pelas partes.", Galeno de Lacerda, op. cit. pg. 132. 
busca da verdade material (arts. 130 e 131 do CPC) mas também considerando a hipossuficiência, em regra, dos beneficiários da Previdência.

Considerando o significado do princípio da manutenção do valor real conforme a interpretação dada pelos Tribunais Superiores, parece-nos indispensável nas perícias contábeis o cotejo do reajustamento concedido no período considerado (ou seja, tomado a partir do último reajustamento ou da data de início do benefício, caso se discuta o primeiro reajustamento) com a variação, dentro do mesmo período, de todos os índices oficiais de inflação.

Não olvidamos que um dos princípios fundamentais do Estado Brasileiro é o da separação e independência dos poderes. Note-se que a leitura hodierna é outra: o princípio é o da separação harmônica dos poderes, garantida através de um sistema de freios e contrapesos pelo qual um poder controla o outro evitando abusos. Como parte desse sistema está o controle de constitucionalidade de leis e atos normativos.

O Legislador pode no exercício da competência que lhe foi atribuída pelo Constituinte, aplicar no reajustamento dos benefícios previdenciários qualquer índice inflacionário oficial: pode conferir o de maior variação ou o de menor variação; aquele apurado com base nos gastos de uma família de uma das principais cidades metropolitanas que perceba até três salários mínimos OU aquele baseado na variação do mercado atacadista. Não importa. Em que pese a distorção que a escolha possa aparentar, o Legislador teria optado por algum dos índices inflacionários oficiais, exercendo sua atribuição no campo mínimo de discricionariedade que o Constituinte The atribuiu. $O$ que não pode fazer é conferir reajustamento abaixo de qualquer índice inflacionário.

Concluindo-se pela inconstitucionalidade da norma, o que fazer? Aplicar o anterior regime de reajustamento já que em regra a nulidade da norma inconstitucional faz revigorar a eficácia da lei por ela anteriormente revogada? Esta não é necessariamente a opção a ser adotada.

Considerando que cada reajustamento visa a repor perdas ocorridas em um determinado período anterior à sua edição, a lei que o determina sempre vai estar relacionada com um momento histórico e econômico pretérito. Um novo período se aproxima e cumpre verificar neste novo interregno a ocorrência de perdas e seu o montante. Uma lei dita inconstitucional e conseqüentemente nula não enseja automaticamente a aplicação do critério de reajustamento revogado dada a especificidade de sua edição. Do contrário, o prejuízo que se quer afastar do beneficiário pode ser mantido ou mesmo ampliado.

Considerando que do leque de índices inflacionários existentes o Legislador poderia ter optado por qualquer deles, desde o de maior variação ao de menor, parece-me ser este o mínimo assegurado ao beneficiário cuja aplicação pelo Juiz no caso concreto não implica em invasão de competência. Nesse sentido socorre-nos o princípio geral de direito traduzido pelo brocardo jurídico: "quem pode o mais, pode o menos".

Evidentemente, não pode o Juiz ao julgar a questão determinar que $o$ índice escolhido para ser aplicado ao caso concreto seja permanentemente aplicado ao benefício. Em primeiro lugar porque a lei teve sua constitucionalidade questionada 
para verificar-se a reposição de perdas em período pretérito. Há uma delimitação temporal de análise da questão.

Em segundo lugar haveria invasão de competência se o Juiz, substituindo-se ao legislador, fixasse um regime de reajustamento imutável. Não podemos nos esquecer que o objeto da ação é uma relação jurídica continuativa ou de trato sucessivo e que o estabelecimento do regime a discipliná-la é de competência do Poder Legislativo, submisso porém ao princípio constitucional. A decisão judicial apenas integra a lacuna uma vez verificada a inconstitucionalidade da norma que, de forma insuficiente, não repôs as perdas passadas e, conseqüentemente, não preservou o valor real do benefício ${ }^{12}$. Conforme lição da Procuradora do INSS, Dra. Patricia Gomes Teixeira, "a superveniência de lei nova " instituindo novo critério de reajuste "demarca a extensão do julgado nas ações revisionais de benefício".

Especialmente na hipótese em que, decorrido lapso de tempo que ultrapasse a periodicidade de reajustamento anteriormente fixada, não tenha sido editada norma a respeito e uma vez verificada perda em relação a todos os índices inflacionários estamos não mais diante de inconstitucionalidade comissiva mais sim omissiva, passível inclusive de proteção pela via do Mandado de Injunção. Esta via, porém, apresenta-se inútil face ao esvaziamento do remédio promovido pelo Eg. STF.

O Juiz não pode ser tímido no exercício de seu mister nem eximir-se de exercê-lo. Para suplantar eventuais barreiras criadas no mais das vezes por qualquer dos Poderes Constituídos, deve ele agir com as armas que o sistema jurídico lhe assegura com a finalidade última de garantir aos indivíduos o exercícios dos direitos previstos na própria Lei Fundamental, armas essas que hoje são inúmeras.

Estas, portanto são as considerações que trago baseadas em raciocínio lógico e nos princípios fundamentais de nosso ordenamento jurídico que aqui formulo com o intuito único de buscar a efetividade da norma constitucional, especialmente em atenção aos já por demais espoliados beneficiários da Previdência. Em última análise, porém, trata-se da defesa de toda Sociedade já que a todo cidadão interessa a preservação, aplicação e efetividade da Constituição. Os direitos assegurados na Lei Fundamental não podem estar jamais submetidos à mera vontade de qualquer Poder Constituído.

12 vide "Ação revisional de benefícios: aspectos da coisa julgada", de Patrícia Gomes Teixeira, in Revista da Procuradoria Geral do INSS, vol. 5, pg.82/86. 